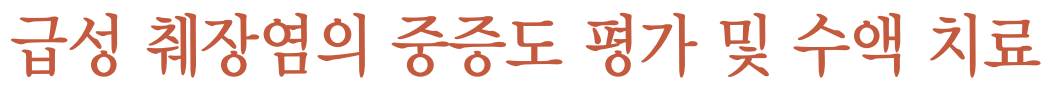

계명대학교 의과대학 내과학교실

이윤석 · 조광범

\title{
Assessment of Severity and Fluid Administration in Acute Pancreatitis
}

\author{
Yoon Suk Lee, Kwang Bum Cho \\ Departments of Internal Medicine, Keimyung University School of Medicine, Daegu, Korea
}

Acute pancreatitis is one of the potentially life-threatening diseases with a wide spectrum of severity. The estimated mortality rate for all patients with acute pancreatitis is approximately $5 \%$. Severe pancreatitis often takes a clinical course with two overlapping phases, an early and a late phase, with two peaks of mortality. According to the revised Atlanta classification system, acute pancreatitis can be divided into mild, moderately severe, or severe. It is important to identify patients with potentially severe acute pancreatitis who require aggressive early treatment. It is believed that intravenous fluid resuscitation is an important variable for improved outcomes in acute pancreatitis. Most guidelines encourage targeting fluid resuscitation toward correcting hypotension, correcting hemoconcentration, and maintaining adequate urine output. In this review article, I would like to discuss the assessment of severity and fluid administration in acute pancreatitis.

Keywords: Acute pancreatitis, Severity, Fluid therapy

\author{
Received Oct. 1, 2015 \\ Revised Nov. 13, 2015 \\ Accepted Dec. 14, 2015
}

Corresponding author : Kwang Bum Cho

Department of Internal Medicine, Keimyung University Dongsan Medical center, 56 dalsungro, Jung-gu, Daegu 41931, Korea

Tel. +82-53-250-7088 Fax. +82-53-250-7422

E-mail; chokb@dsmc.or.kr

This is an Open Access article distributed under the terms of the Creative Commons Attribution Non-Commercial License (http:/ creativecommons.org/licenses/by-nc/3.0/) which permits unrestricted non-commercial use, distribution, and reproduction in any medium, provided the original work is properly cited.

Copyright $@ 2016$ by The Korean Journal of Pancreas and Biliary Tract

\section{서 론}

급성 췌장염은 중증도가 높은 경우 생명을 위협할 수 있는 심각한 질환이다. 발생빈도는 적게는 14.7 명/100,000명/년 (네덜란드), 많게는 45명/100,000명/년(일본)으로 보고되고 있으나, ${ }^{1,2}$ 일반적으로 30 명-45명/100,000명/년으로 알려져 있다.-5 췌장염의 발생빈도는 최근에 증가하는 양상을 보이 는데, ${ }^{6}$ 인구의 고령화 및 비만인구의 증가에 따른 담도성 췌 장염의 발생증가 때문인지, 영상의학적 진단기술의 발달로 인한 진단율의 향상에 따른 것인지는 논란이 있다. 췌장염으 로 인한 사망률은 나라마다 차이가 있으며 대략 $5 \%$ 정도로 보고되나, 조직괴사에 감염이 동반된 경우에는 20-30\% 정도 로 매우 높게 보고되고 있다. ${ }^{7.8}$
급성 췌장염의 중증도를 분류하기 위해서 여러 가지 방법 이 제안되었지만, 평가 변수가 많고 복잡하여 임상적으로 적 용하기에 어려움이 많았다. 따라서, 최근에는 비교적 적은 수의 변수만을 이용하여 간편하게 사용할 수 있는 방법도 개 발되었고, ${ }^{9} 2012$ 년 개정된 아틀란타 분류법에 따르면 급성 췌장염은 경증, 중등증, 중증 췌장염으로 구분되며, 중증도 가 심할수록 예후는 좋지 않은 것으로 알려져 있다. ${ }^{10}$

급성 췌장염의 치료는 금식을 포함하여 통증 치료, 감염예 방, 국소 및 전신적 합병증 치료, 영양요법 및 단백분해저해 제 등 여러 방법을 고려해야 한다. 하지만, 현재까지 보고된 연구에 의하면 가장 중요한 근간을 이루는 치료는 적절한 수 액공급과 금식이다. ${ }^{11}$ 경증 췌장염의 경우 금식과 적절한 수 액투여만으로도 회복될 수 있지만, 중등증이나 중증의 경우 
에는 초기 24 시간내의 적극적인 수액요법과 중증 환자 치료 법에 따른 합병증 관리가 사망률을 줄이는데 도움이 된다. ${ }^{12}$ 급성 췌장염의 초기에 다량의 정맥내 수액투여는 모세혈관 의 순환을 촉진시켜 사망률을 감소시킬 수 있다고 알려져 있 으나, ${ }^{13,14}$ 과량의 수액투여는 오히려 합병증을 증가시킨다는 상반된 결과도 있다. 따라서, 본 고찰에서는 급성 췌장염의 중증도 분류 및 수액 치료에 대한 기존의 지식을 살펴보면서 최근의 연구성과를 바탕으로 변화된 점이 있는지 살펴보고 자 한다.

\section{급성 췌장염의 자연경과}

급성 췌장염의 병태생리에 대해서 여러 가설이 제안되고 있으나, 정확한 발생기전은 아직 완전히 규명되어 있지 않 다. '자가소화(autodigestion)'라고 알려진 기전으로 조기활 성화가 된 소화효소들이 췌장염을 야기하며, 조절되지 못한 염증반응고리의 활성화로 전신적 합병증이 발생한다는 설 명이다. 뿐만 아니라, 다양한 cytokines, chemokines가 췌장 염의 중증도와 관련이 있고, 이들 중 혈중 IL-6나 IL-6 의존 성 급성기단백질(IL-6 dependent acute phase protein) 수치, C-reactive protein (CRP)이 췌장염의 중증도 예측에 있어서 좀 더 신뢰성 있다는 보고가 있다. ${ }^{15,16}$

대부분의 급성 췌장염은 경증의 경과를 취하며 수일 이내 에 저절로 회복이 된다. 그러나 $15-20 \%$ 가량의 환자에서는 중증의 경과를 취하면서 치명적일 수 있는 국소 및 전신적 합병증이 발생된다. 2012년 개정된 아틀란타 분류에 따르면 급성 췌장염은 전기(early phase)와 후기(late phase)의 임상 경과를 취하며 중증도는 질환의 경과 과정에서 급격히 변화 할 수 있다고 알려져 있다. ${ }^{10}$ 전기는 7-10일 정도 지속되며 췌 장염증으로 cytokines 고리가 활성화되어 전신적 염증반응 현상(systemic inflammatory response syndrome, SIRS)이 발 생하고, 모세혈관투과성 증가, 복강이나 흉곽내 체액저류, 신기능부전 등이 발생할 수 있다. SIRS가 지속되면 장기부전 이 발생할 가능성이 높아지며, 전기에서 중증도의 구분은 장 기부전의 존재 유무와 그것이 48 시간 이상 지속되는 지를 기 준으로 한다. 일부에서는 적절한 치료로 48 시간 이내에 장기 부전이 회복되기도 한다. 이어서 전기와 후기의 경계라 할 수 있는, 전신염증반응과 보상작용이 혼합된 mixed antagonist response syndrome 시기를 거쳐 후기의 염증반응이 억제된 compensatory, anti-inflammatory response syndrome
(CARS)으로 진행한다고 알려져 있으나 과정이 복잡하며 그 기전이 완전히 밝혀지지 않았다. ${ }^{10} \mathrm{CARS}$ 동안에는 면역기능 이 감소되어 있고 장관벽의 완전성이 깨어지면서 장관 밖으 로 세균 이동이 쉽게 일어날 수 있다. 따라서 췌장 및 주변부 의 괴사조직에서 감염의 가능성이 높아지며, 패혈증, 다발성 장기부전, 국소 및 전신합병증이 지속되면 사망까지 발생할 수 있다. ${ }^{17,18}$

\section{진 단}

일반적으로 급성 췌장염은 1) 췌장염의 특이적인 복통, 2) amylase/lipase가 정상치의 3 배 이상 증가, 3 ) 췌장염에 합당 한 영상의학적 검사결과, 이렇게 세 가지 기준 중에서 두 가 지 이상을 만족시킬 때 진단될 수 있다. 따라서 통증의 위치 나 양상, 심한 정도, 담석 유무, 음주력, 약제 복용력 등에 대 한 자세한 병력청취와 생화학적 혈액검사의 확인이 필요하 다. 또한, 췌장염이 의심되지만 다른 질환과 감별이 필요할 때는 복부 computed tomography $(\mathrm{CT})$ 를 포함한 영상학적 검사를 시행하여 확인하게 된다.

\section{중증도 평가}

급성 췌장염의 중증도 평가 방법은 매우 다양하며 국소적 또는 전신적 합병증 유무와 관련이 있다. 중증 급성 췌장염 에서는 주로 호흡기나 신장의 기능부전이 48 시간 이상 지속 되며, CT에서 췌장내 및 주변부 괴사조직이 관찰되는데 높 은 사망률과 관련이 있어 적극적인 치료가 요구된다. 중증도 판단과 분류는 예후에 밀접한 영향을 미치기에 한 번만 하는 것이 아니라 수시로 평가해야 한다. 초기에는 지속적인 SIRS 가 있는지, 초기 장기부전이 있는지, 다양한 예측인자를 통 하여 중환자실 치료나 다른 상급병원에 전원할지 여부를 판 단한다. 입원 이후의 중증도 판단은 환자의 상태가 더욱 명 확해진 상태이므로 중증도 정도에 따라 효과적인 치료법을 정하는데 도움이 된다.

\section{1. 급성 췌장염의 중증도 분류}

1992년도에 아틀란타 분류법이 개발되어서 여러 해 동안 사용되었지만 장기부전의 가변성을 반영할 수는 없었다. 그 러던 중 2012년에 아틀란타 분류법이 새로 개정되었고, 중증 도의 분류를 다음과 같이 3 개로 나누었다. 1) 중증 급성 췌장 
염(severe acute pancreatitis): modified Marshall 분류법으로 2단계 이상의 중증도를 보이는 장기부전(단발성 또는 다발 성)이 48 시간 이상 지속되는 경우, 2) 중등증 급성 췌장염 (moderately-severe acute pancreatitis): 새롭게 추가된 부분 으로서 입원기간이 길어지거나 중재시술이 필요한 국소합 병증 유무에 상관없이 일시적인(48시간을 지속하지 않는) 장기부전이나 기존의 질환이 악화되는 경우, 3) 경증 급성 췌 장염(mild acute pancreatitis): 장기부전이 전혀 없으면서 국 소적이나 전신적 합병증이 없는 경우로 구분된다(Table 1). ${ }^{10}$

256명을 대상으로 1992년 아틀란타 분류법, 2012년 개정 된 아틀란타 분류법 그리고 determinant-based classification (DBC)을 전향적으로 비교연구한 결과를 보면 1992년 분류 에 비하여 2012년 개정된 아틀란타 분류법이나 DBC가 사망 률(area under the curve [AUC] 0.89 for both vs. $0.76, p$ $<0.001$ ), 중환자실(intensive care unit, ICU) 입원 (AUC 0.91 for both vs. $0.80, p<0.001$ ), ICU 치료기간 (Somer's D 0.21 and 0.28 vs. $0.07, p<0.05$ ) 등을 더 잘 예측할 수 있었 다. ${ }^{19}$ 또한 459 명을 대상으로 한 후향적 연구에도 2012년 개 정된 아틀란타 분류법을 적용하였을 때 경증, 중등증, 중증 의 비율이 $67 \%, 30 \%, 4 \%$ 였으며, 이들간에 입원기간이나 ICU 치료 필요성, 중재적 시술, 사망률 등이 의미 있게 차이 가 있었다. ${ }^{20}$

그러나 553명을 대상으로 ICU 입원, 재원기간, 사망률 등 을 보고한 국내의 후향적 관찰 코호트 연구를 보면 장기부전 뿐만 아니라 감염성 괴사가 사망률을 올리는데 독립적으로 기여함을 보여주었다. 즉 장기부전은 없으나 감염성 괴사가 있는 경우와 장기부전은 있으나 감염성 괴사가 없는 경우의 환자의 사망률은 비슷하였다 $(7.1 \%$ vs. $8 \%)$. 또한 장기부전 이 있으면서 감염성 괴사가 동반한 경우에는 사망률이 급격 히 상승하였다 $(32.3 \%$ vs. $8 \%)$. 이는 감염성 괴사 자체가 췌

Table 1. Grades of severity: revision of the Atlanta classification (2012)

Mild acute pancreatitis
- No organ failure
- No local or systemic complications
Moderately severe acute pancreatitis
- Organ failure that resolves within $48 \mathrm{~h}$ (transient organ failure)
and/or
- Local or systemic complications without persistent organ failure
Severe acute pancreatitis
- Persistent organ failure (>48 h)
- Single organ failure
-Multiple organ failure

장염의 중증도를 높인다고 볼 수 있겠으며, 2012년 개정된 아틀란타 분류법에도 제한점이 있음을 시사한 것으로 향후 추가 개정의 여지를 보여 주었다. ${ }^{21}$

\section{2. 점수 체계}

급성 췌장염의 경과는 전기와 후기로 나뉘는데, 급성 췌장 염으로 인한 조기 사망은 대부분 입원 후 7-14일 이내에 SIRS가 발생하면서 급격하게 장기부전을 일으키면서 발생 한다. ${ }^{18}$ 특히 입원시 높은 acute physiology and chronic health evaluation II (APACHE II) 점수를 가지는 중증 급성 췌장염 환자에서 초기에 48시간 이상 지속하는 장기부전을 보이는 경우에 특히 사망률이 더 높다. ${ }^{22}$ 따라서 중증 췌장염 으로 진행하거나 위험도가 높은 환자를 선별하는 것이 치료 에 중요하다. 이를 위하여 여러 가지 점수 체계를 이용한 방 법이 개발되었으나 장단점을 내포하고 있다.

외래에서 치료 가능한 경증의 환자를 가려내기 위한 것으 로는 harmless acute pancreatitis score (HAPScore)가 개발 되었고, 반발통이나 복부경직이 없으면서, 정상 hematocrit, 정상 혈청 creatitnine을 보이는 경우 양성 예측도가 $98 \%$ 라 고 보고되었다. ${ }^{23}$

1970년도에 개발된 Ranson's critieria가 췌장염의 중증도 를 예측하기 위한 방법으로 오랫동안 사용되어 왔다. 입원 시와 48 시간 후의 인자들을 측정하여 중증도를 예측하는 방 법으로, 3점 이상일 경우 중증 췌장염으로 진행에 대한 민감 도와 특이도가 $83.9 \%, 78 \%$ 라 하였고 음성 예측도가 $94.5 \%$ 로 높았다. 그러나 측정 요인이 많고 입원 후 48시간이 지나 기 전에는 중증도를 판단할 수 없어 그 사용에 제한이 있다. ${ }^{24}$

현재 사용되는 점수 체계로서 중증도를 판단하는데 있어 서 가장 민감도가 높은 것은 APACHE II 점수 측정법이다. 8 점 이상일 때 민감도 $65-83 \%$, 특이도 $77-91 \%$, 양성 예측도 $23-69 \%$, 음성 예측도 86-99\%로 알려져 있다. ${ }^{24,25}$ 그러나 14 개 항목 이상을 포함하고 있기에 복잡하고, 사용에 시간이 소요되어 제한이 있다.

최근 더 간편하게 사용할 수 있는 bedside index of severity in acute pancreatitis (BISAP) 점수 측정법이 개발되었다 (Table 2). ${ }^{9}$ Blood urea nitrogen (BUN) (>25 mg/dL), impaired mental status (Glasgow coma scale $<15$ ), SIRS 유무, 나이 $(>60)$, 흥막 삼출액 유무에 따라서 각각 1점을 부여하 였다. 3 점 이상일 경우 민감도 $83 \%$, 양성 예측도 $76.9 \%$ 로서 사망률 $5 \%$ 이상임을 시사하였다. ${ }^{9}$ 단지 단점으로는 일시적 
Table 2. Bedside Index for Severity in Acute Pancreatitis (BISAP) score and observed mortality

\begin{tabular}{|c|c|}
\hline \multicolumn{2}{|c|}{ Clinical variables (1 point allocated per variable) } \\
\hline \multicolumn{2}{|c|}{$\mathrm{BUN}>25 \mathrm{mg} / \mathrm{dL}$} \\
\hline \multicolumn{2}{|c|}{ Impaired mental status (Glasgow coma scale $<15$ ) } \\
\hline \multicolumn{2}{|c|}{ SIRS, defined by the presence of two or more } \\
\hline \multicolumn{2}{|c|}{ Temperature $<36^{\circ} \mathrm{C}$ or $>38^{\circ} \mathrm{C}$} \\
\hline \multicolumn{2}{|c|}{ Heart rate $>90$ / minute } \\
\hline \multicolumn{2}{|r|}{ Respiratory rate $>20$ / minute or $\mathrm{PaCO} 2<32 \mathrm{mmHg}$} \\
\hline \multicolumn{2}{|r|}{ WBC $<4,000 / \mathrm{mL}$ or $>12,000 / \mathrm{mL}$ or $>10 \%$ immature band } \\
\hline \multicolumn{2}{|c|}{ Age $>60 \mathrm{yr}$} \\
\hline \multicolumn{2}{|c|}{ Pleural effusion } \\
\hline \multicolumn{2}{|c|}{ BISAP score and corresponding mortality (\%) } \\
\hline 0 & $0.1-0.2$ \\
\hline 1 & $0.5-0.7$ \\
\hline 2 & $1.9-2.1$ \\
\hline 3 & $5.3-8.3$ \\
\hline 4 & $12.7-19.3$ \\
\hline 5 & $22.5-26.7$ \\
\hline
\end{tabular}

BUN, blood urea nitrogen; SIRS, systemic inflammatory response syndrome; WBC, white blood cell; BISAP, bedside index for severity in acute pancreatitis

장기부전과 장기적 장기부전 환자를 구분하지 못하여 중증 도를 과잉 예측할 소지가 있다는 것이다.

그 외에도 modified Marshall, multiple organ dysfunction score (MODS), modified MODS (Bernard score), sequential organ failure assessment 등이 개발되어 사용되기도 한다.

결국 점수 체계를 이용한 중증도 예측은 음성 예측도는 높 지만 양성 예측도가 상대적으로 낮아서 이상적이지 않다. 그 렇지만 중요한 장점은 경증의 환자를 선별하여 남은 환자들 에 집중할 수 있게 하는 것이다.

\section{Laboratory markers}

$\mathrm{CRP}$ 는 염증에 의하여 생성된 IL-1이나 IL-6이 간세포를 자극하여 합성하는 급성 반응단백질로서 질환이 발생한 지 72 시간 내에 뒤늦게 생성된다. CRP 수치는 감염성 괴사가 있는 환자에서는 다발성 장기부전 여부나 무균성 괴사의 유 무와 관련 없이 증가한다. $150 \mathrm{mg} / \mathrm{L}$ 이상일 때 민감도, 특이 도, 양성 예측도, 음성 예측도는 각각 $61 \%, 90 \%, 78 \%, 79 \%$ 이었으며, 입원 당시 측정값보다 24-48시간이 지난 후 측정 하는 것이 더욱 나았다. 그러나 $\mathrm{CRP}$ 는 질병 특이적이지 않 아서 모든 염증성 질환에서 증가할 수 있으며, 감염성 괴사 나, 장기부전, 사망을 예측하는 데에는 한계가 있다.

중증 급성 췌장염에서 소화효소가 풍부한 췌장 삼출액 및
염증성 매개체의 작용으로 인하여 국소적 염증이 발생하고, 이로 인해서 결국 혈관내 체액이 제 3 의 공간으로 유출된다. 혈관내 체액 감소는 혈액농축과 혈청 hematocrit의 상승을 일으키는데 이로 인하여 췌장내 미세순환의 장애로 췌장 괴 사가 발생하게 된다. ${ }^{14}$ 특히 hematocrit이 $44 \%$ 이상일 때 양 성 예측도는 낮으나(입원 당시 $26 \%, 24$ 시간 후 $27 \%$ ) 높은 음성 예측도(입원 당시 $93 \%, 24$ 시간 후 $97 \%$ )를 보여 장기부 전을 예측할 수 있는 중요한 지표라고 하였다. ${ }^{14}$

또한 BUN도 혈관내 체액량을 반영하면서 급성 췌장염의 중증도를 예측하는데 약간의 도움이 될 수 있다. 이와 관련 된 코호트 연구를 보면, 비생존자가 생존자에 비하여 지속적 으로 48시간 BUN 수치가 높았으며(F-test, $p=0.0001$ ), 첫 24 시간 이내에 BUN 수치가 $5 \mathrm{mg} / \mathrm{dL}$ 씩 증가할수록 사망률 이 2.2배 증가하였다(odds ratio [OR] 2.2, 95\% confidence interval [CI]: 1.8-2.7). 또한 입원시, 24시간 그리고 48시간 사망률을 예측하는 $\mathrm{AUC}$ 는 각각 $0.79,0.89,0.90$ 으로 주기적 혈청 BUN 수치 측정은 신뢰성 있게 사망률을 예측할 수 있 었다. ${ }^{26}$

그 외에 pentaxin 3, procalcitonin, IL-6, IL-8, TNF- $\alpha$, trypsinogen activation peptide 등이 실험실적으로 연구되고 있으나 상업적으로 사용하기에는 유용하지 못하였다. ${ }^{16}$

\section{4. 영상학적 검사}

급성 췌장염의 많은 환자에서 입원 당시에는 CT가 꼭 필 요하지는 않다. 특히 알코올에 의한 경미한 재발성 췌장염에 서 더욱 그렇다. 그러나 임상적으로 병의 경과가 악화되는 추세라면 조영증강 CT 촬영을 시행하여 간질성 췌장염과 고 사성 췌장염을 감별할 수 있으며, 감염성 괴사나 가성동맥류 와 같은 합병증을 발견할 수도 있다. 뿐만 아니라, CT 소견을 이용하여 급성 췌장염의 중증도를 평가할 수 있고, Balthzar 등급 및 궤사 유무에 대한 점수를 종합하여 CT severity index를 구할 수 있다. ${ }^{27}$ 일반적으로 가장 심한 급성 췌장염 은 장기부전과 췌장괴사가 있는 경우로서 grade $\mathrm{E}$ 췌장염이 다. Balthzar-Ranson 중증도 기준은 비조영증강 CT 등급과 조영증강 후 판단한 괴사의 정도(없음, $30 \%$ 미만, $30-50 \%$, $50 \%$ 이상)를 기준으로 하고 있다. 4 점 이상일 때 음성 예측 도는 94-97\%이며, 양성 예측도는 53-69\%로 높아서 영상을 이용한 점수 체계로는 가장 많이 사용되고 있다. 


\section{수액 치료}

대부분의 경증 급성 췌장염 환자들은 외래단위에서도 치 료가 가능하지만, Ranson'score $>3$, BISAP score $>3$, $\mathrm{APACHE}$ II score $>8$ 일 경우에는 중증도가 심하기에 집중 치료를 하여야 한다. 중증 췌장염 환자에서 사망은 주로 초 기 7-14일 이내에 발생하므로 초기의 효과적인 치료법을 찾 기 위한 노력들이 많이 있어 왔으며, 원인 치료와 통증조절, 영양 치료, 수액 치료, 약물 치료 등이 있지만 수액요법 이상 의 결과를 보고한 약제는 없는 실정이다.

\section{1. 수액투여 용량 및 속도}

중증 급성 췌장염 환자가 응급실을 통하여 내원하였을 때 가장 중요한 것 중의 하나는 초기에 다량의 정맥내 수액공급 을 하는 것이다. 혈액농축은 신관류를 감소시키고 췌장내 미 세혈액순환의 장애를 일으켜 괴사성 췌장염과 장기부전을 야 기하며, 더 나아가 사망률을 높이게 한다. ${ }^{14}$ 따라서 hematocrit 이나 BUN/Cr을 적절하게 유지하기 위하여 다량의 수액을 조 기에 투여하였을 때 미세혈액순환을 개선시키고 췌장괴사를 예방할 수 있다고 하였다. ${ }^{26,28}$ 그러나 다량의 수액이 투여되었 을 때 폐부종이 발생할 가능성이 있으므로 적절한 양을 투여 하는 것이 중요하다.

수액투여에 대한 많은 연구들은 대체로 초기 24시간 이내 에 평균 $4.5 \mathrm{~L}$ (3.5-5.4 L) 정도의 용량을 투여한 적극적 투여 군과, $3.5 \mathrm{~L}(1.7-4.0 \mathrm{~L})$ 정도를 투여한 비적극적 투여군으로 나누어 비교를 하였다. ${ }^{11}$ 적극적 투여군에서 좋은 결과를 보 인 연구로서 Warndorf 등 ${ }^{29}$ 의 연구를 들 수 있으며, 434 명을 대상으로 72 시간 동안 사용할 수액의 $1 / 3$ 이상을 초기 24 시 간 이내에 투여한 군과 이후에 투여한 군을 후향적으로 비교 하였다. 적극적 투여군에서 SIRS가 24시간째( $15 \%$ vs. $32 \%$, $p=0.001), 48$ 시간째( $14 \%$ vs. $33 \%, p=0.001), 72$ 시간째 $(10 \%$ vs. $23 \%, p=0.001)$ 에서 모두 의미 있게 감소하였고, 72 시간째 장기부전도 의미 있게 감소되었다 $5 \%$ vs. $10 \%, p$ $<0.05)$. 또한 중환자실로의 입원율도 감소되었고 $6 \% \mathrm{vs.}$ $17 \%, p<0.001$ ), 재원기간도 짧았다 ( 8 일 vs. 11 일, $p=0.01$ ). 이런 현상은 특히 입원시 간질성 췌장염이 있었던 군에서 더 욱 저명하였다. ${ }^{29}$ 또 다른 45 명을 대상으로 한 후향적 관찰연 구에서도 조기에 적극적으로 수액투여한 군이 사망률이 의 미 있게 낮았다 $(0 \%$ vs. $18 \%, p<0.04) .^{30}$

그러나 최근 발표된 전향적 연구에서는 초기의 과도한 수
액투여가 폐부종, 복수 및 복강내압을 증가시키며, 과도한 혈액희석을 야기함으로써 예후가 나쁘고, 비적극적 수액투 여군에서는 수액의 과량투여로 인한 합병증이 감소되기에 오히려 예후가 좋음을 보고하였다. ${ }^{31,32} 247$ 명을 대상으로 초 기 24시간 이내에 투여된 수액량이 3.1 L 미만, 3.1-4.1 L, 4.1 L 이상인 3 군으로 나누어 시행한 전향적 코호트연구를 보면, 초기 24 시간 이내 $4.1 \mathrm{~L}$ 이상 투여된 군에서 의미 있게 높은 지속적 장기부전과 체액저류, 호흡기부전, 신부전이 발생하 였다. 반면에 $3.1 \mathrm{~L}$ 미만 투여된 군에서는 장기부전이나 국소 합병증, 사망률이 관찰되지 않았고, 초기 24시간 이내 3.1$4.1 \mathrm{~L}$ 를 투여된 군에서 가장 좋은 결과를 보였다. ${ }^{31}$ 또 다른 115 명을 대상으로 초기 48시간 이내 hematocrit을 빨리 교정 한 군(<35\%)과 천천히 교정한 군(>35\%)을 비교한 전향적 연구를 보면, 빨리 교정한 군에서 총 투여된 수액량이 입원 시, 24시간, 48 시간째 많았고, 두 군 사이에 초기 7일 동안 hematocrit, oxygenation index, $\mathrm{pH}, \mathrm{APACHE}$ II scores, 장 기부전이 차이가 있었다. 그리고 빠른 교정군에서 패혈증 진 행하는 기간이 더 빨랐고(7.4 \pm 1.9 vs. $10.2 \pm 2.3$ 일 $), 28$ 일째 패혈증의 빈도( $78.6 \%$ vs. $57.6 \%)$ 도 높았으며 생존율도 낮았 다( $66.1 \%$ vs. $84.7 \%, p<0.05){ }^{32}$

이 결과를 미루어 보면 수액공급은 빠를수록 좋겠으나, 초 기에 너무 많은 양의 수액공급은 장기부전의 증가, 췌장주위 저류액의 증가, 신부전, 호흡기부전, 중환자실 입원율 증가, 사망률 증가, 복부 분획증후군, 패혈증 등을 조장할 수 있기 에 지양하는 것이 좋겠으며, 3-4 L 정도를 초기 24시간 내에 환자 상태에 따라 투여하는 것이 좋겠다.

\section{2. 수액의 종류}

그러나 어떤 종류의 수액이 가장 효과적인지는 논란이 있 다. 40명을 대상으로 lactated Ringer' solution과 생리식염수 를 이용하여, 혈청 $\mathrm{BUN}$ 치를 주기적으로 측정하여 투여량을 결정한 군(goal- directed)과 그렇지 않은 군(standard) 등 총 4 군에게 수액투여를 시행한 전향적 연구를 보면, 총 투여된 수액양은 goal directed군이나 standard 투여군 사이에 차이 (평균 4,300 vs. $4,600 \mathrm{~mL}, p=0.87$ )가 없었고, SIRS의 빈도 (11.8\% vs. $13 \%, p=0.85), 24$ 시간 후 CRP 수치(87.1 vs. $69.2 \mathrm{mg} / \mathrm{dL}, p=0.75)$ 는 차이가 없었다. 그러나 lactated Ringer' solution을 투여한 군에서 생리식염수를 투여한 군 에 비하여 24 시간 후 SIRS 빈도가 의미 있게 감소하였고 (84\% reduction vs. $0 \%, p=0.035)$, CRP 수치도 감소시켰다 
$(51.5$ vs. $104 \mathrm{mg} / \mathrm{dL}) .^{33}$ 또 다른 연구로서 41 명을 대상으로 초기 8일 동안 lactated Ringer' solution 단독으로 사용한 군 과 hydroxyethyl starch를 같이 사용한 군을 비교하여 급성 췌장염의 초기에 hydroxyethyl starch가 복압에 미치는 영향 을 조사한 연구를 보면, hydroxyethyl starch를 투여하였을 때 2-7일 동안에 의미 있게 복압이 감소하였고, 인공호흡기 를 적용한 환자비율도 적었다 $(15.0 \%$ vs $47.6 \%, p<0.05)$. 그 리고 negative fluid balance도 더 빨리 이룰 수 있었다(2.5 \pm 2.2 vs. $4.0 \pm 2.5$ days). ${ }^{34}$

\section{3. 수액투여의 목표}

급성 중증 췌장염에서 적절한 혈관내 체액량을 유지하기 위하여 BUN, central venous pressure (CVP), hematocrit, 심 박수, 혈압, 소변량 등 여러 가지 지표가 이용된다. 혈청 $\mathrm{BUN}$ 치를 주기적으로 측정하여 투여량을 결정한 군(goaldirected)과 그렇지 않은 군(standard)을 비교한 연구를 보면 goal-directed군에서도 CRP 호전이나 SIRS에 더 영향을 미 치지 않았다. ${ }^{33} \mathrm{CVP}$ 또한 오랫동안 사용되어 왔으나 정확한 수액투여량 결정에는 도움이 되지 않는다. 그에 반하여 hematocrit을 이용한 연구에서는 논란이 있다. 즉 입원시 hematocrit $>44 \%$ 이상이었던 39명 (28 necrotizing, 11 Interstitial)을 대상으로 입원시와 24시간에 hematocrit을 비 교한 연구를 보면, 24 시간 이내에 hematocrit이 감소되지 않 았던 군에서 의미 있게 괴사성 췌장염이 많이 발생하였다 (12/28명 vs. 0/11, $p=0.009) .{ }^{35}$ 그러나 최근에 115 명을 대상 으로 초기 48 시간 이내 hematocrit을 빨리 교정한 군 (<35\%)과 천천히 교정한 군(>35\%)을 비교한 전향적 연구 를 보면, 빨리 교정한 군에서 패혈증으로 진행하는 기간이 더 짧았고(7.4 \pm 1.9 vs. $10.2 \pm 2.3$ 일), 28 일째 패혈증의 빈도 (78.6\% vs. $57.6 \%)$ 도 더 높았으며 생존율도 낮았다 $(66.1 \%$ vs. $84.7 \%, p<0.05){ }^{32}$

또한, 내시경적 역행성 담췌관조영술 시행 후 급성 췌장염 이 발생한 45 명의 환자를 대상으로 protocol-based 수액투여 (32명)군과 경험적 수액투여(13명)군을 비교한 후향적 연구 에서는 protocol-based 투여군이 경한 임상경과를 밟았고 $(\mathrm{OR}=11.2 ; 95 \% \mathrm{CI}: 1.9-68.7, p=0.002)$, 짧은 재원기간을 가졌으며 (7 vs. 3 일, $p=0.01)$, CT 촬영 비율이나(100\% vs. $15.6 \%, p<0.001)$, 항생제 사용률이 낮았다 $(50 \%$ vs. $3.1 \%, p$ $=0.01$.

일본의 급성 췌장염 권고안에서는 수액의 종류는 우선적
으로 lactated Ringer'액을 추천하며, 탈수나 입원 초기에 shock에 빠진 경우에는 초기에 150-160 mL/h 속도로 주의 깊게 투여하며, 탈수가 없는 환자의 경우는 $130-150 \mathrm{~mL} / \mathrm{h}$ 의 속도로 투여하기를 권고한다. 또한 수액요법 중에는 소변량 은 최소 $0.5 \mathrm{ml} / \mathrm{kg} / \mathrm{h}$ 이상, 평균 동맥압은 $65 \mathrm{mmHg}$ 이상 되 도록 유지 하여야 하는데, 이 조건을 만족하면 수액 투여속 도를 낮추면서 순환혈액량을 재확인하여 투여속도를 조절 하는 것을 권고한다. ${ }^{36}$

\section{결 론}

급성 췌장염을 치료하는데 있어서 빠른 중증도 판단과 적 절한 수액 치료는 예후에 중요한 영향을 미친다. 여러 가지 의 중증도 분류 기준이 있지만 장단점이 있어 사용하는 기관 마다, 입원상황마다 필요성을 달리한다. 2012년 개정된 아틀 란타 분류법이 일반적으로 도움이 되겠으며, 간편하게 사용 할 수 있는 BISAP 점수나, ICU에서의 APACHE II 점수 등도 사용할 수 있겠다.

적절한 수액 치료는 급성 췌장염의 치료에 있어서 가장 중 요한 치료법 중 하나이다. 그렇지만 투여 용량 및 속도에 대 해서는 상충되는 연구결과가 존재하므로 결국은 어떤 수액 을 어떤 속도로, 어떻게 투여할 건지에 대한 더 나은 연구들 을 기대하게 된다. 초기 24시간 이내에 3-4 L 가량의 lactated Ringer'액을 환자의 상태에 따라 투여하는 것이 좋겠으나, 순 환혈액량을 평가하면서 적절하게 조절하여야 하겠다.

\section{요 약}

급성 췌장염은 중증도가 높은 경우 생명을 위협할 수 있는 심각한 질환이다. 2012년 개정된 아틀란타 분류법에 의하면 경증, 중등증, 중증 급성 췌장염으로 분류되며, 중증 급성 췌 장염의 임상경과는 초기 및 후기로 구분될 수 있다. 췌장염 으로 인한 사망은 대부분 입원 후 7-14일 이내에 발생하며 급 격하게 장기부전을 일으키면서 발생한다. 특히 입원시 높은 APACHE II 점수를 가지는 중증 급성 췌장염 환자에서 초기 에 48 시간 이상 장기부전이 지속되는 경우 사망률이 더 높 다. 따라서 중증 급성 췌장염으로 진행하거나 위험도가 높은 환자를 선별하는 것은 치료에 중요하다. 이를 위하여 여러 가지 점수 체계를 이용한 예측방법이 개발되었으나 장단점 을 내포하고 있다. 
확정적인 약물 치료법이 개발되지 않은 현 시점에서 수액 치료는 급성 췌장염의 치료에 있어서 통증 치료나 국소 및 전신적 합병증 치료, 영양요법 등과 함께 근간을 이루는 가 장 중요한 치료법이다. 초기에 너무 많은 양의 수액공급은 장기부전의 증가, 췌장주위 저류액의 증가, 신부전, 호흡기 부전, ICU 입원율 증가, 사망률 증가, 복부 분획증후군, 패혈 증 등을 조장할 수 있기에 지양하는 것이 좋겠으며, 3-4 L의 lactated Ringer'액을 초기 24시간 내에 환자 상태에 따라 적 절히 투여하는 것이 좋겠다. 또한 수액 치료 중 순환혈액량 을 종합하여 관찰하면서 수액투여용량을 적절하게 조절하 여야 하겠다.

국문 색인: 급성 췌장염, 중증도, 수액요법

\section{Conflicts of Interest}

The author has no conflicts to disclose.

\section{REFERENCES}

1. Spanier B, Bruno MJ, Dijkgraaf MG. Incidence and mortality of acute and chronic pancreatitis in the Netherlands: a nationwide recordlinked cohort study for the years 1995-2005. World J Gastroenterol 2013;19:3018-3026.

2. Satoh K, Shimosegawa T, Masamune A, et al. Nationwide epidemiological survey of acute pancreatitis in Japan. Pancreas 2011;40:503507.

3. Roberts SE, Akbari A, Thorne K, Atkinson M, Evans PA. The incidence of acute pancreatitis: impact of social deprivation, alcohol consumption, seasonal and demographic factors. Aliment Pharmacol Ther 2013;38:539-548.

4. Shen HN, Lu CL, Li CY. Epidemiology of first-attack acute pancreatitis in Taiwan from 2000 through 2009: a nationwide population-based study. Pancreas 2012;41:696-702.

5. Frey CF, Zhou H, Harvey DJ, White RH. The incidence and case-fatality rates of acute biliary, alcoholic, and idiopathic pancreatitis in California, 1994-2001. Pancreas 2006;33:336-344.

6. Yadav D, Lowenfels AB. Trends in the epidemiology of the first attack of acute pancreatitis: a systematic review. Pancreas 2006;33:323330.

7. Pavlidis $\mathrm{P}$, Crichton S, Lemmich Smith J, et al. Improved outcome of severe acute pancreatitis in the intensive care unit. Crit Care Res Pract 2013:2013:Article ID 897107.

8. Banks PA, Freeman ML. Practice guidelines in acute pancreatitis. Am J Gastroenterol 2006;101:2379-2400.
9. Wu BU, Johannes RS, Sun X, Tabak Y, Conwell DL, Banks PA. The early prediction of mortality in acute pancreatitis: a large populationbased study. Gut 2008;57:1698-1703.

10. Banks PA, Bollen TL, Dervenis $C$, et al. Classification of acute pancreatitis--2012: revision of the Atlanta classification and definitions by international consensus. Gut 2013;62:102-111.

11. Haydock MD, Mittal A, Wilms HR, Phillips A, Petrov MS, Windsor JA. Fluid therapy in acute pancreatitis: anybody's guess. Ann Surg 2013; 257:182-188.

12. Fisher JM, Gardner TB. The "golden hours" of management in acute pancreatitis. Am J Gastroenterol 2012;107:1146-1150.

13. Baillargeon JD, Orav J, Ramagopal V, Tenner SM, Banks PA. Hemoconcentration as an early risk factor for necrotizing pancreatitis. Am J Gastroenterol 1998;93:2130-2134.

14. Brown A, Orav J, Banks PA. Hemoconcentration is an early marker for organ failure and necrotizing pancreatitis. Pancreas 2000;20:367372.

15. Leser HG, Gross V, Scheibenbogen $C$, et al. Elevation of serum interleukin- 6 concentration precedes acute-phase response and reflects severity in acute pancreatitis. Gastroenterology 1991;101:782-785.

16. Staubli SM, Oertli D, Nebiker CA. Laboratory markers predicting severity of acute pancreatitis. Crit Rev Clin Lab Sci 2015:52;273-283.

17. Gunjaca I, Zunic J, Gunjaca M, Kovac Z. Circulating cytokine levels in acute pancreatitis-model of SIRS/CARS can help in the clinical assessment of disease severity. Inflammation 2012;35:758-763.

18. Besselink MG, van Santvoort HC, Boermeester MA, et al. Timing and impact of infections in acute pancreatitis. Br J Surg 2009;96:267-273.

19. Nawaz H, Mounzer R, Yadav D, et al. Revised Atlanta and determinant-based classification: application in a prospective cohort of acute pancreatitis patients. Am J Gastroenterol 2013;108:1911-1917.

20. Acevedo-Piedra NG, Moya-Hoyo N, Rey-Riveiro M, et al. Validation of the determinant-based classification and revision of the Atlanta classification systems for acute pancreatitis. Clin Gastroenterol Hepatol 2014;12:311-316

21. Choi JH, Kim MH, Oh D, et al. Clinical relevance of the revised Atlanta classification focusing on severity stratification system. Pancreatology 2014;14:324-329.

22. Johnson $C D$, Abu-Hilal M. Persistent organ failure during the first week as a marker of fatal outcome in acute pancreatitis. Gut 2004;53: 1340-1344.

23. Lankisch PG, Weber-Dany $B$, Hebel $K$, Maisonneuve $P$, Lowenfels AB. The harmless acute pancreatitis score: a clinical algorithm for rapid initial stratification of nonsevere disease. Clin Gastroenterol Hepatol 2009;7:702-5; quiz 607.

24. Yeung YP, Lam BY, Yip AW. APACHE system is better than Ranson system in the prediction of severity of acute pancreatitis. Hepatobiliary Pancreat Dis Int 2006;5:294-299.

25. Gravante G, Garcea G, Ong SL, et al. Prediction of mortality in acute pancreatitis: a systematic review of the published evidence. Pancre- 
atology 2009;9:601-614.

26. Wu BU, Johannes RS, Sun X, Conwell DL, Banks PA. Early changes in blood urea nitrogen predict mortality in acute pancreatitis. Gastroenterology 2009;137:129-135.

27. Balthazar EJ, Robinson DL, Megibow AJ, Ranson JH. Acute pancreatitis: value of CT in establishing prognosis. Radiology 1990;174:331336.

28. Wall I, Badalov N, Baradarian R, Iswara K, Li JJ, Tenner S. Decreased mortality in acute pancreatitis related to early aggressive hydration. Pancreas 2011;40:547-550.

29. Warndorf MG, Kurtzman JT, Bartel MJ, et al. Early fluid resuscitation reduces morbidity among patients with acute pancreatitis. Clin Gastroenterol Hepatol 2011;9:705-709.

30. Gardner TB, Vege SS, Chari ST, et al. Faster rate of initial fluid resuscitation in severe acute pancreatitis diminishes in-hospital mortality. Pancreatology 2009;9:770-776.

31. de-Madaria E, Soler-Sala G, Sanchez-Paya J, et al. Influence of fluid therapy on the prognosis of acute pancreatitis: a prospective cohort study. Am J Gastroenterol 2011;106:1843-1850.

32. Mao EQ, Fei J, Peng YB, Huang J, Tang YQ, Zhang SD. Rapid hemodilution is associated with increased sepsis and mortality among patients with severe acute pancreatitis. Chin Med J (Eng) 2010;123: 1639-1644.

33. Wu BU, Hwang JQ, Gardner TH, et al. Lactated Ringer's solution reduces systemic inflammation compared with saline in patients with acute pancreatitis. Clin Gastroenterol Hepatol 2011;9:710-717.e1.

34. Du XJ, Hu WM, Xia Q, et al. Hydroxyethyl starch resuscitation reduces the risk of intra-abdominal hypertension in severe acute pancreatitis. Pancreas 2011;40:1220-1225.

35. Brown A, Baillargeon JD, Hughes MD, Banks PA. Can fluid resuscitation prevent pancreatic necrosis in severe acute pancreatitis? Pancreatology 2002;2:104-107.

36. Yokoe M, Takada T, Mayumi T, et al. Japanese guidelines for the management of acute pancreatitis: Japanese Guidelines 2015. J Hepatobiliary Pancreat Sci 2015;22:405-432. 